\title{
Automotive manufacturing technologies - an international viewpoint
}

\author{
Steven Peters ${ }^{1, *}$, Gisela Lanza ${ }^{1}$, Jun $\mathrm{Ni}^{2}$, Jin Xiaoning ${ }^{2}$, Yi Pei-Yun ${ }^{3}$, and Marcello Colledani ${ }^{4}$ \\ 1 Institute of Production Science (wbk), Karlsruhe Institute of Technology, Kaiserstrasse 12, 76131 Karlsruhe, Germany \\ $2 \mathrm{Wu}$ Manufacturing Research Center, University of Michigan, Ann Arbor, USA \\ 3 School of Mechanical Engineering, Shanghai Jiao Tong University, Shanghai, P.R. China \\ 4 Department of Mechanical Engineering, Politecnico di Milano, 20156 Milan, Italy
}

Received 15 June 2014 / Accepted 28 July 2014

\begin{abstract}
The automotive industry can be described as a backbone in many developed countries such as Japan, Korea, USA, and Germany, while being an enabler for economic prosperity in developing countries like China, Brazil, Eastern Europe, and Russia at the same time. However, the dynamics and uncertainty are increasing heavily by market changes, regulations, customer behavior, and new product technologies. Manufacturing research has to find answers to increase quality of products, flexibility of plants, and supply chain networks, to manage complexity in technologies and variants and overall to stay competitive even in high wage countries. In this paper, major technological challenges are discussed and the current state of manufacturing technology and research is presented. Moreover, for each technological and organizational area, future industrial, and research challenges are highlighted.
\end{abstract}

Key words: Manufacturing technologies, Automotive industries, Sustainable mobility

\section{Motivation}

Cars represent the pursuit of freedom of each individual like nothing else. The relevance of the automotive industry for economic prosperity and its impact on jobs can be seen in all major markets and countries. Interestingly, both developed and developing countries see this industry as their backbone. While the industry in TRIAD countries (USA, Japan, and EU) became a high-tech branch, BRIC countries (Brazil, Russia, India, and China) started with simpler products.

In the European Union, about 16 million units are manufactured, which is about $26 \%$ of the world's annual production. Hence, cars are one of the most important products with an annual turnover of about 700 billion Euro [1]. There are about 2 million direct jobs and another 10 million in related manufacturing and other sectors within the automotive industry in the EU (including truck, suppliers, etc.). With its 210 production plants in Europe, the automotive industry exports 75 billion Euro of net trade every year [1]. It is also the largest sector in private $R \& D$ investments with more than 5,800 patents in 2011 [1]. Being the most important player in Europe's automotive industry, Germany has more than 750,000 employees working directly in the automotive sector in more than 45 plants [1]. The automotive industry in the USA accounts for between

*e-mail: steven.peters@kit.edu
$4 \sim 5 \%$ of the US gross domestic product and employed 716,900 people in 2011 [2]. In Japan, almost 790,000 people work directly in the automotive industry [3].

It is expected that the BRICs' share of global vehicle sales will edge towards the 50\% mark by 2018 [4] and TRIAD and BRIC markets are expected to converge in terms of customer demands and behavior within the next 5-6 years. As a matter of fact, China has already become the world's largest automobile producer and market since 2009 [5]. The current 5-year plan of the Chinese administration prepares China for a market-share of $30 \%$ of all cars in the world [6] and the Chinese government views the development of the new energy vehicle industry as a top priority and has introduced policies and incentives in its favor [4].

The presented figures illustrate the importance of the automotive industry for all major economies. However, this leading industry faces tough challenges due to emission limitations and public opinion (compare [7]), unsustainable surge in petroleum consumption, high volatility and a (temporarily) low utilization of capacity. In the automotive industry the number of jobs depends to a high extent on manufacturing and consequently so does the prosperity of an economy. Facing the mentioned challenges means technological progresses in both, product and production. In the following, selected technological approaches are discussed and the current state of manufacturing technology and research is presented. Moreover, for each 
technological and organizational area, future industrial, and research challenges are highlighted.

The paper is therefore organized as follows: firstly current state and roadmaps of selected core technologies with tremendous impacts on manufacturing are given, secondly some key enablers and also organizational issues are presented, before the paper ends with some final remarks. No specific scientific methodology was used to come up with the roadmap. Instead, this viewpoint is driven by an ad hoc method to provide a general assessment as well as a projection of future advanced automotive manufacturing technologies.

\section{Core technologies for future automotive production}

\subsection{Battery technology and its manufacturing}

Today, batteries for battery electric vehicles (BEV) and hybrid cars are usually based on Li-ion technology holding on to achieve $250 \mathrm{Euro} / \mathrm{kWh}$ on system level within a couple of years. However, there are several different designs such as pouch cells (so called coffee bags), prismatic cells and round cells. Round cells, which are coiled, require a well-known process technology and can be produced fast in an established roll-to-roll process. Pouch cells are more complex in handling and automation, but enable the easy separation of single, imperfect sheets, which are identified by in-line optical inspection while building up a stack out of hundreds of coated sheets. Approaches like Z-folding [8] of the separator try to combine both types of cells, but are generally based on pouch cells. One major challenge is the lack of knowledge of, and experience with the long-term behavior of the batteries ("breathing cells"), their chemical performance depending on battery management, the number and shape of cycles (e.g. fast charging), and the dependence on climate conditions. To enhance reliability prognosis and identify real critical quality characteristics, improved electro-chemical and thermal models of Li-Ion-Batteries are needed [9]. Figure 1 shows a coated cathode on Al-foil in battery production.

Due to the next generation of coating materials, slurries, and electrolytes manufacturing processes will have to be adapted again. Therefore, there is only limited time to earn the costs of the very expensive equipment. Moreover, variable costs are very high for instance for the air-conditioned dry chambers. At the same time, the amount of sold electric cars is not expected to reach dimensions of an automotive mass production within the next 10 years. Furthermore, Li-Sulphur, and LiPolymer are expected to become an alternative between 2020 and 2025 [10]. Li-Air is a promising option which is in focus of Volkswagen and IBM among others [11]. The US Department of Energy (DOE) even expects Li-Air technology to be ready in 2020 [12]. Alternative approaches deal among others with Li-Magnesium (e.g. Samsung, LG, Toyota) [11]. Advanced batteries could compete or assist the fuel cell one day.

To gain knowledge and boost ramp-up new cooperations occur: Robert Bosch GmbH, GS Yuasa, and Mitsubishi started a joint venture. Recently a huge research project

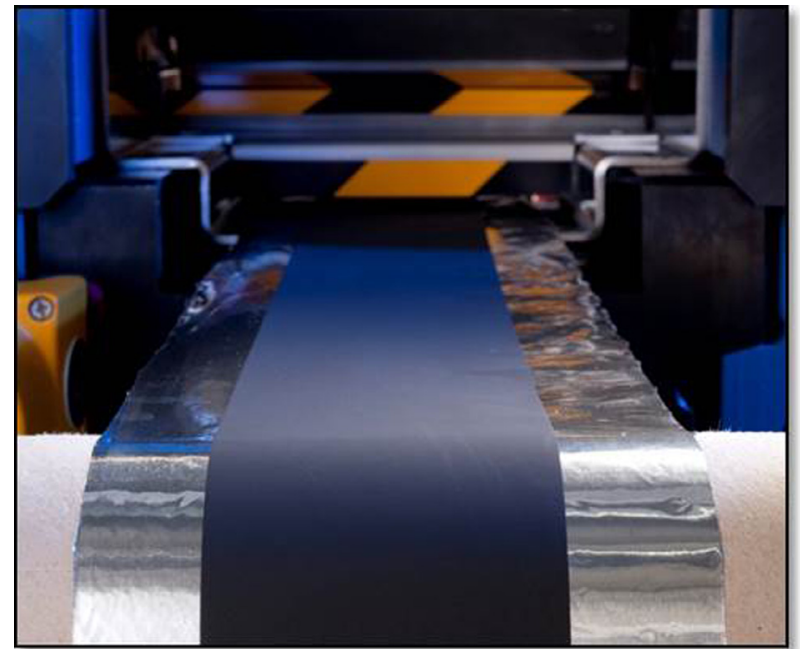

Figure 1. Development of automotive batteries focuses on reducing material costs, reducing mass and improving durability. Core technologies are automation, type-flexible lines and in-line quality inspection devices. (Picture: KIT)

"Alpha-Laion" (funded by the German government) with Bosch, Daimler, BMW, BASF, Wacker, and SGL started with the goal to develop Li-Ion batteries enabling a range of $300 \mathrm{~km}$ by BEV.

The leading-edge cluster "CLUSTER ELECTRIC MOBILITY SOUTH-WEST" plays an important role in the industrialisation of a strongly performing, low-emission and marketdriven mobility system of the future in Germany.

\subsection{Fuel cell technology and its manufacturing}

Fuel cell vehicles (FCV), with hydrogen as energy carrier, have the potential to significantly reduce the dependence on fossil fuels and lower harmful emissions. Proton exchange membrane fuel cells (PEMFCs), enjoying merits of quick start-up, zero emission and high efficiency, are considered to be the most promising candidate for FCVs [13]. However, several challenges must be overcome before these vehicles will be competitive with conventional vehicles. From a technological point of view, costs, and durability are the two greatest barriers for the commercialization of FCVs. On the one hand, the fuel cell costs for mass production have been reduced from \$275/ $\mathrm{kW}$ in 2002 to $\$ 73 / \mathrm{kW}$ in 2008 . This corresponds to almost $\$ 6,000$ for an $80 \mathrm{~kW}$ system, which is still more than twice as expensive as internal-combustion engine systems [14]. In 2011, the cost further decreased to $\$ 49 / \mathrm{kW}$ for an $80 \mathrm{~kW}$ (net) integrated transportation fuel cell power system, however, they are still higher than the US Department of Energy's (DOE) target to reach $\$ 30 / \mathrm{kW}$ by 2015 [15]. The largest part of a fuel cell's cost is the membrane electrode assembly (MEA) that consists of a Nafion ${ }^{\circledR}$ membrane and platinum-based catalyst. The Pt loading has been reduced by two orders of magnitude in the past decade and there is still room for further loading reduction [16]. Another important factor is the improvement of manufacturing technology for bipolar plates (BPPs), which account for $40 \%$ of the total stack costs [17]. Metallic BPPs, 


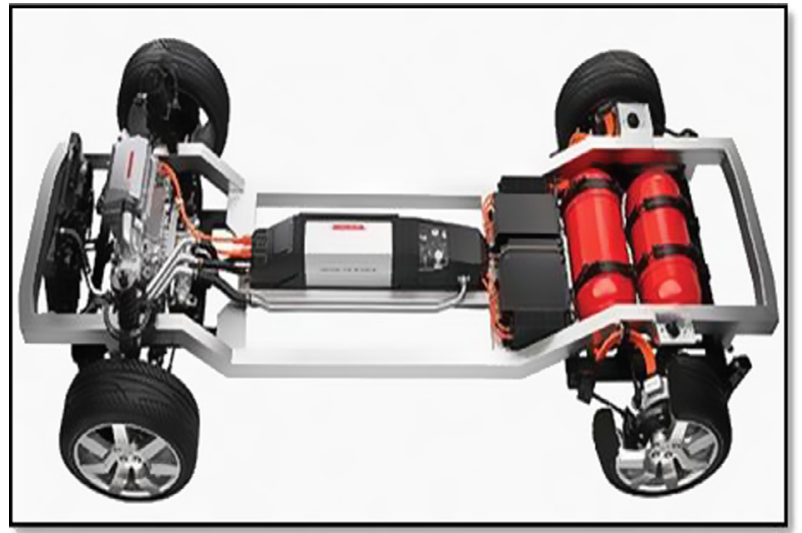

Figure 2. Development of fuel cells focus on material costs and durability. Core technologies are ultra-low Pt catalysts, metallic bipolar plates and advanced automation in production. (Picture: Honda Motor Co.)

with $0.1 \mathrm{~mm}$ stainless steel sheets as raw material and stamping process as mass production method, can reduce the costs more than conventional graphite BPPs [18]. Another target of the DOE is to achieve a life time of $5,000 \mathrm{~h}$ durability with less than a $10 \%$ decay in performance for FCVs by 2015 [15]. Both MEA and BPPs suffer degradation during long-term operations. At the moment, most fuel cells show a major performance decay after approximately $1,000 \mathrm{~h}$ of usage $[19,20]$. However, it is reported that $3 \mathrm{M}$ Company recently achieved over $7,500 \mathrm{~h}$ of service lifetime for the membrane electrode assembly (MEA) during their single-cell testing on the laboratory level, making it possible to meet the DOE's 2015 target [16]. Besides, a multilayer carbon film coated on the surface enables the metallic BPPs to meet the durability requirement $[21,22]$. It should also be noted that the production, storage, end-use, and infrastructure of hydrogen are still issues that need to be solved before commercialization. Figure 2 shows an approach of Honda.

From a political point of view, governments, and companies around the world are supporting further development and commercialization of hydrogen and fuel cell technologies through policies and incentives. Germany, for example, has launched one of the largest programs in the world: the "National Hydrogen and Fuel Cell Technology Innovation Programme (NIP)" [23]. The US government provided $\$ 41.9$ million for the Recovery Act to accelerate fuel cell commercialization and deployment. The California Fuel Cell Partnership released "A California Road Map: Bringing Hydrogen Fuel Cell Vehicles to the Golden State", stating that with an estimated 53,000 vehicles on the road by 2017 , more than 100 stations will be built to ensure that the network has enough capacity for additional vehicles [24]. The Japanese car manufacturers Toyota, Honda, and Nissan committed to launch programs for cars powered by fuel cells in four metropolitan areas by the year 2015. Moreover, Korea, and Japan are working on fuel cell power plants and communication infrastructure [23]. China is in its 12th Five-Year Economic Development Plan (20112015). The Ministry of Science and Technology (MOST) has approved a budget of 738 million RMB for electric vehicle (EV) R\&D, of which 21\% (155 million RMB) are designated for FCVs. Shanghai Automotive Industry Corporation (SAIC), one of the largest car manufacturers in China, announced that there will be about 1,000 FCVs assembled by the end of 2015 [25]. Furthermore, there is a string of alliances created for the advancement of the commercialization for FCVs in 2013. General Motors and Honda Motor Co. will partner to develop a common system for FCVs, while Toyota Motor Corp. and BMW AG paired up on a fuel-cell production alliance. Besides, Daimler AG, Ford Motor Co., and Nissan Motor Co. announced that they would jointly develop a line of affordable fuel cell electric cars for sale as early as 2017. In summary, the potential of FCVs has been well recognized worldwide, although the fuel cell technology and most of all infrastructure still need further advancement. Commercialization of FCVs is expected to begin around 2015 and the overall popularization might be around 2050 [26].

\subsection{Hybrid lightweight construction and its manufacturing}

In order to increase the fuel efficiency and driving agility of cars, lightweight strategies must be developed - especially with respect to increasing efforts and weights caused by safety restrictions and additional features such as entertainment devices. However, the requirements depend on the vehicle segment and volume. For the future, it is likely that a multimaterial approach will be used in many modern vehicle designs, which may include next-generation AHSS (advanced high strength steel), $\mathrm{Al}, \mathrm{Mg}$, metal matrix compounds, composites, etc. Furthermore steel provides huge remaining potentials as demonstrated by the FutureSteelVehicle [27]. The new US Institute "Lightweight \& Modern Metals Manufacturing Innovation (LM3I) Institute" focuses on lightweight by innovative metals [28]. USDrive gives a brief overview of significant challenges in the current material technology roadmaps [29]. Nanotechnology plays an important role in future development of advanced metals (compare [30]) as well as microtechnology which will enable functional surfaces for instance (compare "surface engineering" [31]). In the meanwhile near-net-shaping and forming will be continuously improved to enable a reduction of waste and additional processes in production while reducing weight at the same time.

When talking about composites, the automation of process chains including in-line inspection, when hybridizing metals and fiber-reinforced plastics, is an important precondition for series production [32]. Especially the technologies and devices for handling and joining (mechanical, thermal and chemical) are very complex (compare Figure 3 ) and of crucial importance for short cycle times in production and long durability in the field. Davies gives a comprehensive overview of component manufacturing and materials joining technologies [33].

At the moment, an improved Resine Transfer Molding (RTM) process is a promising way to reduce cycle times in the production of CFRP down to less than 3 min [34]. During the next years, $R \& D$ in composite technology is likely to focus on the improvement of the RTM technology with for example high-pressure injection and compression [35]. New handling technologies may be based on controlled vacuum or ultra-sonic 


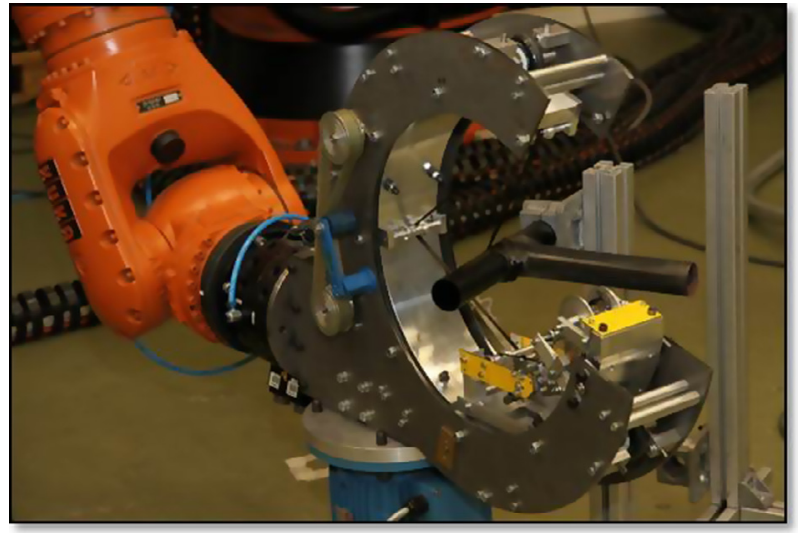

Figure 3. Efforts in lightweight construction and manufacturing focus on multi material understanding (corrosion, thermal expansion), shortening of cycle times and cutting costs of materials. Core technologies are predictive modelling as well as handling, joining and automation. (Picture: KIT)

handling devices that neither damage the sheets nor pollute them with any additional materials [36]. The integration of patches with metal inserts enables a multi-material mix and mechanical joining such as screwing or welding. Again, re-manufacturing and recycling become more and more important for separating the different materials of the car body, e.g. by thermal treatment in pyrolytic processes or by mechanical processes. Moreover, the carbon footprint from cradle to grave has to be concerned when talking about composites. A revolution in CFRP might be possible by alternative (e.g. ligninbased) pre-cursors [34].

From 2020-2025 onwards, multi-material-designs, probably based on improved metallic structures (but also compare "Multimaterial Space Frame" by Audi), could be used to be enriched with an intelligent mix of highly specialized automotive steels, $\mathrm{Al}, \mathrm{Mg}$, thermoplastics and maybe organic sheets as well as CFRP, GFRP. The long-term goal might be a functionintegrated and system-oriented lightweight design like the one demonstrated in the project $\mathrm{InEco}^{\odot}$ [37]. One of the most ambitious approaches in the market can be seen by BMW AG with the latest concepts for BMW i3 and i8 as well as the innovative Joint Venture SGL Automotive Carbon Fibers (ACF) between SGL Group and BMW Group. A very comprehensive roadmap on lightweight approaches was presented by the Automotive Council UK [38].

\subsection{Additive manufacturing}

Today, additive manufacturing as "production on demand" is widely used in rapid prototyping, tooling, surface coating and producing or repairing dies. Mortara et al. [39] has presented a comprehensive classification of additive manufacturing technologies e.g. by types of energy or used materials. Using laser is currently one of the most common approaches for working on metal powders in the automotive area. The market of such photonic technologies is expected to grow significantly until 2015 [40]. Additive manufacturing has not been used for components in series production of cars. However, applications of selective laser melting (SLM) in the aerospace industry show

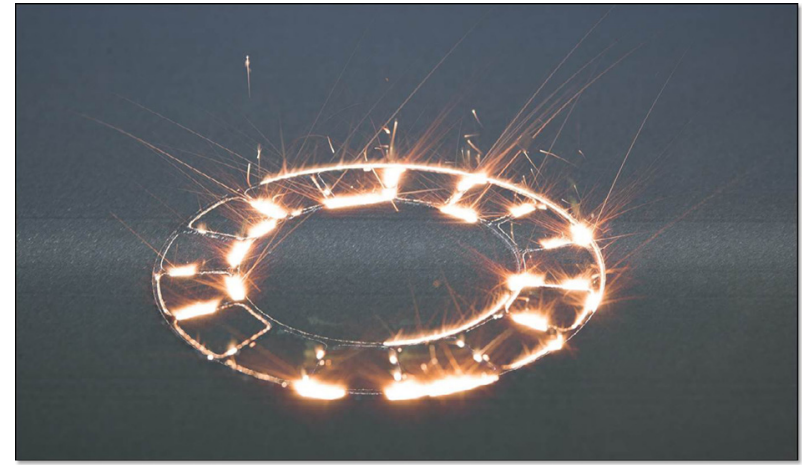

Figure 4. Development focuses on shortening cycle times and cutting costs (e.g. for materials) as well as on increasing reproducibility. Core technologies are holistic optimization of chains and material models. (Picture: Fraunhofer ILT)

promising results for almost all kinds of very complex (usually small) geometries or highly individualized components. GE has announced to produce 40,000 parts per year by additive manufacturing starting in 2018 [41]. In the future, material models are required in order to simulate the process and increase the overall understanding of the process. Multichamber systems, hybrid automats with integrated cutting tools and in-process quality inspection are not only key research fields, but also lead to an ongoing increase in the build-up rate. The key approach to an application in series production involves an integrated view of new designs, knowledge of material behavior and increased process technologies (Figure 4). A "simple" substitution of process technologies used for existing parts, however, is not promising at all. On the one hand, the potential of a new paradigm "Manufacturing for Functionality" (compare [42]), which enables new function integrated parts, must replace the restrictive philosophy of "Design for Manufacturing". This means that for the first time, designers are not confined by manufacturing restrictions in terms of reacting to the customers' requirements. On the other hand, the whole value chain from design to assembly can be shortened, for example by using SLM-automats or 3D-printers closer to or even in final assembly lines, in order to produce the parts "just in time" and "right there". Moreover, additive manufacturing can be used to fabricate innovative new materials with defined microstructural patterns [43]. Although the technology has revolutionary potential, substantial work needs to be done regarding the "improved performance in terms of power, beam properties, efficiency, and size, as well as better spatial \& temporal control and stability - and all at lower cost" [40]. Roland Berger expects tremendous improvements in built-up rates until 2018 [44]. The "National Additive Manufacturing Innovation Institute (NAMII)" in the US [45] was founded and is funded to strengthen additive manufacturing technologies. NAMII established an "Innovation Factory" in Youngstown, Ohio. At the same time huge initiatives have been started in Europe (especially in UK and Germany) while China has probably the largest amount of papers published on the SLM technology (compare SCOPUS). [46] and [47] have provided comprehensive roadmaps on digital- and direct-manufacturing technologies. 


\subsection{Flexible manufacturing of body in white}

In this context, flexible manufacturing (FM) is, in its essence, the capability of making different vehicles on the same line without long delays due to tool change. The key technologies of FM for body in white are extensive use of robots and supervisory computers. Cooperating robots are one of the major innovations in automation during the last years. Today cooperating multi-axes robots can be controlled in real-time during handling processes of whole body in whites. No work men are needed to finish a body in white, starting from the coil. Usually the body in white production comes before the order penetration point, where parts are adjusted to the customers' requirements. Consequently, frames are not named to a specific customer in terms of a push production. Those highly efficient systems of today will have to become more flexible in variants and materials, as customers expect more individualization. However, modern welding guns and positioning devices usually depend on a pre-defined, single geometry and the designed opening spaces of the frames are very limited. To this aim, a promising welding technology to ensure the required flexibility level, also reducing energy consumption $(-30 \%)$, tooling requirements and processing times ( $20 \%$ of spot welding), is represented by Remote Laser Welding (RLW). By having laser optics embedded into the robot and a scanning mirror head as the end-effector, RLW can easily create joints in different locations of the product through simple robot repositioning and laser beam redirection from a remote distance (e.g. 0.898$1.22 \mathrm{~m}$ from last mirror to the welding target). Volkswagen has been playing a pioneering role in RLW area. The German automaker has been progressively introducing robot-guided YAG laser welding to its body shops over the past years and has adopted an innovative hybrid welding process combining laser and arc welding for door assembly. As much as $75 \%$ of body in white has been welded by this technology e.g. for Golf [48].

However, it is already possible to make completely different vehicles on the same line without delays due to vehicle change. For example, in the Toluca plant, Chrysler can manufacture the PT Cruiser and Dodge Journey interchangeably although they share only a few parts through FM systems. In the body shop of Ford, the sheet metal is assembled to form the vehicle's body, yet more than $80 \%$ of the tooling is not model-specific. It can be reprogrammed to weld a car, truck or crossover of similar size. GM has announced to invest \$250 million in Flexible Manufacturing in the Ingersoll Plant. Furthermore, it is reported that $\mathrm{ABB}$ provides a complete body in white welding line to Changan Ford Mazda Automobile Company's (CFMA) new factory in Chongqing. The welding line uses ABB's FlexLean Technology, with ABB's patented FlexTrack and FlexLifter as a flexible conveying system. The advanced flexible solution allows the production of different car models on the same line and will help the manufacturer to improve productivity by $15 \%$.

New context-sensible handling devices adapting to the real geometry are needed in the future to create a defined position in flexible production e.g. for welding or clueing (Figure 5). First steps towards context-sensibility have been discussed for years now, focusing on the usage of RFID tags in product components [49]. As a next step, so called cyber-physical systems

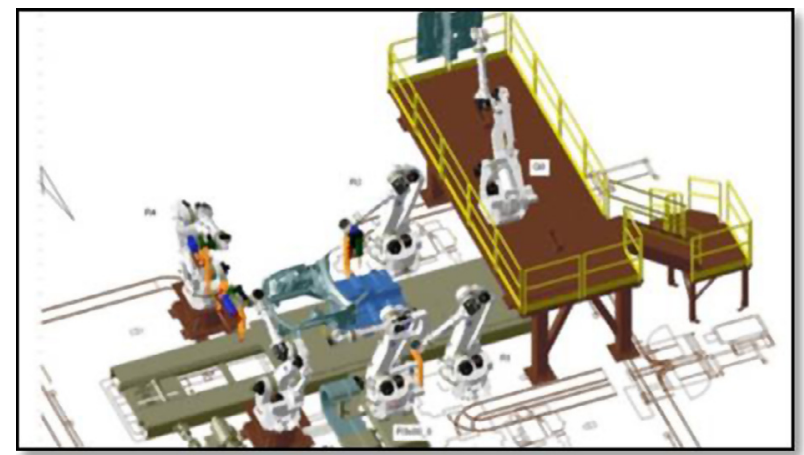

Figure 5. Development focuses on mixed vehicle lines. Core technologies are robots with flexible tools, internet-based control systems and context-sensible handling/joining devices. (Picture: Ford)

are likely to replace RFID, as they use a wireless internet connection to coordinate their needs with the production equipment. Future body in white constructions will mix the best materials available for each requirement in a lifetime of a car. Therefore, joining technologies of tomorrow (see Figure 3) are needed [50]. The overall goal will remain to create all bodies of one car platform on one automated line.

\subsection{Autonomous final assembly}

Today, final assembly lines in automotive series production are characterized by dozens of well-defined work places rowing up in one fixed route. Each station has a fixed work program and a more or less fixed number of employees which can be smoothed by the so called "drifting" of single workers [51]. The cars move along the lines and are assembled in a strict sequence at the stations. The material is delivered to the stations in the order of processing. There are several mixed lines, e.g. in Dingolfing, BMW manufactures the 5-, 6- and 7-series and their derivatives on one final assembly line. Today, robots are only used very little and only in fixed positions and for specific tasks in final assemblies.

The next generation of automotive assembly lines could be influenced by the latest research results (Figure 6) in human-machine collaboration: lightweight robots and humans work together to combine their "individual" performance to achieve the best results for the product. Digital "poka yoke" avoids any mistakes in the assembly by instantly checking the matching IDs via wireless internet. Approaches of augmented reality will change the required profiles of workers and support the increasing complexity and variety of variants. Within the next couple of years, these current fields of research seem to be on their way into series production, with the next generation of lightweight and sensitive robots as well as cyber-physical systems.

Self-moving chassis [52] could revolutionize the conventional fixed routes, as they enable different work packages for different orders. This of course has a high impact on the layout and can therefore only be introduced with a new model. The processes of logistics, the just-in-time delivery and the sequence of material are highly dependent on a forecast, which 


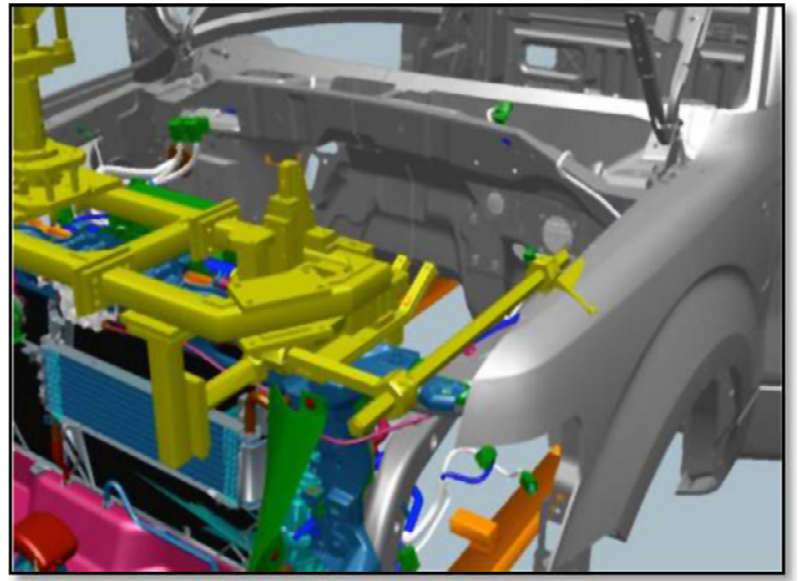

Figure 6. Development focuses on flexible sequencing/scheduling, flexible speed of assembly lines and just-in-time material flow. Core technologies are human-machine collaboration and advanced sensors. (Picture: Ford)

is usually made a few hours before delivery. The loss of a strict sequence leads to the necessity of locating the supplier parks in close proximity of the assembly. Moreover, there is still a need for research on autonomous drives for chassis that enable flexible routes in the assembly (compare [53]). However, this does not seem to be expected before 2020, although very first steps can be seen in modern plants where the engine assembly is flexible and free of static ground-based lines. Within a German "industry on campus" - project called "ARENA 2036" new concepts for flexible final assembly are developed together with Daimler AG.

Within one decade, a solution with non-fixed, undetermined flow speed might be possible, without reducing the overall outcome. All parts would remain in flow by a continuous adaption of the speed and a simultaneous re-scheduling of workloads depending on variants, available employees, technical downtimes and delivery dates in almost real-time. Parallel pits for unusual versions (such as battery electric vehicles) could be used in a kind of by-pass to level the processing times, in order to sustain a continuous flow.

\subsection{Remanufacturing}

The remanufacturing industry has a long-standing relationship with the automotive sector, as vehicle parts and components are subject to significant wear and tear and thus require repairs during their operating life. With the emerging development of electrified vehicles, including hybrid electric vehicles (HEV), plug-in hybrid electric vehicles (PHEV) and battery electric vehicles (BEV), remanufacturing of expensive traction batteries and electronic/mechatronic components has been considered a sustainable strategy for OEMs. The driving force for incorporating remanufacturing as a business strategy is not only the pressure exerted by environmental legislations, but also the economic benefits given the existing salvage technology, reverse supply chains and economic-rational remanufacturing operations $[54,55]$.
Remanufacturing is defined as "an industrial process to recover value from the used and degraded products by re-instating them to "like-new" condition through components replacement or reprocessing" [56]. It recaptures the value of the durable components, as well as some fraction of the original manufactured value. The process of product remanufacturing is usually less expensive than producing a brand new unit, because modules and components can be reused and thus avoid the need to procure new components from suppliers [57]. In fact, the cost of remanufacturing can be between $45 \%$ and $65 \%$ less than the manufacturing cost. Moreover, the willingness to pay for a remanufactured product is only between $9.7 \%$ and $15.3 \%$ lower than for a same new product. Furthermore, remanufacturing processes use $20-25 \%$ of the energy needed to manufacture the same product.

The importance of remanufacturing of automotive products is increased by emerging "Green" responsibilities for, and management of, the end-of-life (EOL) phase. The EU countries, through diverse directives, are trying to regulate the EOL processing of automotive parts and components. The remanufacturing of products or parts is the most significant in terms of resource conservation and in economic terms primarily in relation to the aftermarket supply.

The growing popularity of expensive and sophisticated mechatronic products, such as rack \& pinion steering gears and electric power steering, together with the rising demand for automatic transmissions and diesel engines, is expected to boost the automotive remanufacturing market to a great extent. While in 2007 the average was 16 mechatronic modules per vehicle, in 2011 some vehicles incorporate 60-70 mechatronic modules. Less than $10 \%$ of mechatronic components are currently remanufactured. The most common failures for a mechatronic unit are: in connectors, because they are a weak point in some electronic units for various reasons; in the wiring, for mechanical stress and corrosion; and in the power supply. The failure often consists of a component which can be easily diagnosed and replaced. The ideal core for remanufacturing should have a high remanufacturability rate and a short life cycle, meaning more cores to be collected during the product life cycle. For these reasons, the alternators, starters, and brake calipers are remanufactured by almost $10 \%$ of companies. $\mathrm{AC}$ compressor is in the category of the most remanufactured components as well. Other components are also attractive for remanufacturing but not so commonly processed for technical reasons such as ECUs (Electric Control Units) and transmission. The emerging technical challenges for automotive mechatronic components remanufacturing call for new automated technologies integrating disassembly, reworking and recovery in the same plant. An example of a pilot plant for innovative mechatronic de-manufacturing processes is described in [58]. Remanufactured mechatronic products, which come with competitive warranties and low price points, are expected to become popular aftermarket products in the future.

Research has shown that remanufactured products sales may cannibalize new products sales, however, the sales of remanufactured products increased the overall market share in many instances [59]. Due to fast technological advances and style changes in the automotive industry, direct market cannibalization by remanufactured products is no risk, 
because the remanufactured versions are of an earlier generation.

\section{End-of-life vehicles (ELVs) recycling}

The recycling of End-of-Life vehicles (ELVs) is an increasing concern for vehicle manufacturers due to the rising emphasis on environmental stewardship from customers and within companies, increasing material costs and regulations governing the future recyclability of vehicles. Moreover, the legislation emphasis towards EPR (Extended Producer Responsibility) is bringing car manufacturers to the forefront of end-of-life activities. In 2009, over 9 million ELVs constituting over 8 million tons of waste were collected in the European Union, according to Eurostat. Currently, ELV material recovery rates are in the range of 75-85\% [60], but EU legislation, for example, targets recovery, and re-use rates of $95 \%$, an energy recovery of $10 \%$ and a maximum of $5 \%$ disposal by vehicle weight by the year 2015. Meeting these targets requires both improvements of the current state of recycling technologies and diligent analysis of recyclability in the design phase of new components and materials. The International Dismantling Information System (IDIS) was developed by the automotive industry to meet the legal obligations of the EU End of Life Vehicle (ELV) directive and has been improved to an information system with vehicle manufacturer compiled information for treatment operators to promote the environmental treatment of End-of-Life-Vehicles, safely, and economically.

Material recovery of vehicles remains focused on ferrous metals, with the recovery of high value non-ferrous metals and relatively low value plastics incorporated as recycling demand grows. ELVs are pre-treated by dismantling, which originally served to capture valuable reusable components, but evolved to include the capture of parts with regulated and toxic materials and to isolate components with high material recycling value, such as catalytic converters. After the vehicles are stripped, the hulks are sent to recyclers who shred the vehicles. The remainder of the shredded vehicles (ASR Automotive Shredded Residue) can be used in trash-to-ash schemes or is sent to landfill. While ELV regulation and licensing of dismantlers in the EU serves to ensure that vehicle recycling captures harmful materials in this process, the recovery rates of materials from the ELVs and the quality of the materials recovered is not assured. In particular, market factors, in both new product manufacturing and End-of-Life processing, and EU regulations may conflict in the areas of light metals recycling and plastics and composites recycling.

Advancing beyond the state of the art to achieve higher recycling rates will require opening traditional ELV recycling to new disassembly models and recycling processing techniques. State of the art plastic separation techniques including optical and spectroscopic techniques have difficulty with typical automotive plastics [61]; however, isolating components with a limited number of known plastic species may make these types of separation more feasible. Composite recycling may also benefit from improved disassembly strategies. New techniques for separating high value carbon fiber, more and more used in high-tech, high performance automotive applications may provide an effective way to recapture composite components for reuse [62]; however, the composite material must be isolated effectively through improved recovery strategies and correct size reduction strategies have to be developed to avoid deteriorating the recyclability of the fibers by excessive shredding. Finally, the development of new techniques for enabling the optimized recycling of components with advanced engineered metallic and non-metallic elements will be the basis for deriving guidelines for new legislations that will govern the end-of-life treatment of the vehicles of the future, to be collected in the next $10-15$ years.

\subsection{Summary of core technologies}

The automotive industry is probably facing the most critical challenges in its whole history. Completely new technologies for the powertrain and the body of the car are on their way, new markets in emerging countries prosper and customers' behavior changes rapidly and inhomogeneous. Despite the existing new technologies, internal combustion engines will remain the leading technology for the next decades. Their development has to be focused on including production technologies from efficient casting of new alloys to microstructured surfaces. Some of the most promising technologies emphasizing on manufacturing technologies are presented (see Figure 7).

To manage the changes and to increase the effects of high investments in research and development, new alliances and cooperations are designed. Daimler, Ford, and Nissan are working together in the field of fuel cells. BMW works together with SGL Carbon in the production of lightweight car bodies. On the other hand, synergies between industries have the potential for even more disruptive innovations. Cooperation between automotive and aerospace industries in material and manufacturing technology clusters can lead to even more new ideas.

In the following, some trends of production management aspects and factory design are presented, dealing with the outer effects of manufacturing.

\section{Production management}

\subsection{Near-zero downtime production performance}

With a large degree of automation, the automotive industry needs intelligent machines and maintenance solutions to achieve higher productivity, improved reliability, greater efficiency and complete quality assurance. Most machine maintenance today is either purely reactive (fixing or replacing equipment after it fails) or blindly proactive (assuming a certain level of performance degradation, with no input from the machinery itself, and servicing equipment on a routine schedule whether service is actually needed or not). Both scenarios are extremely wasteful.

The main barriers for predicting health condition/performance of a complex system include: (a) the inability to anticipate unknown faults particularly for complex engineering systems in which hundreds to thousands of sub-systems interact and contribute to the overall system functionality and performance, (b) the inability to sustain system functionality 


\begin{tabular}{|c|c|c|c|c|c|}
\hline Topic & 2014 & 2017 & 2020 & 2025 & Goal \\
\hline $\begin{array}{l}\text { Battery } \\
\text { Technology }\end{array}$ & Li-lon pouch cells & $\begin{array}{l}\text { electrochemical } \\
\text { models, quality } \\
\text { characteristics }\end{array}$ & \multicolumn{2}{|c|}{ Li-Sulphur and Li-Polymer } & Li-Air \\
\hline $\begin{array}{l}\text { Fuel-Cell } \\
\text { Technology }\end{array}$ & $\begin{array}{l}\text { novel catalysts, } \\
\text { batch production } \\
\text { of metallic bipolar } \\
\text { plates }\end{array}$ & $\begin{array}{l}\text { batch production } \\
\text { of MEA and } \\
\text { plates, partially } \\
\text { automated } \\
\text { assembly of stack }\end{array}$ & $\begin{array}{l}\text { mass production } \\
\text { of fuel cell stacks }\end{array}$ & $\begin{array}{l}\text { highly integration } \\
\text { and automation } \\
\text { of fuel cell system }\end{array}$ & $\begin{array}{l}\text { competitive costs } \\
\text { and hydrogen } \\
\text { infrastructure }\end{array}$ \\
\hline $\begin{array}{l}\text { Hybrid } \\
\text { Lightweight } \\
\text { Construction }\end{array}$ & $\begin{array}{l}\text { Al, HSS, } \\
\text { CFRP (RTM, low } \\
\text { automation) }\end{array}$ & \multicolumn{2}{|c|}{$\begin{array}{l}\text { AHSS } 3^{\text {rd }} \text { Gen., Al, Mg, High- } \\
\text { Performance-RTM for CFRP, auto- } \\
\text { mated placement of hybrid structures, } \\
\text { organic sheets, advanced joining }\end{array}$} & $\begin{array}{l}\text { metallic body } \\
\text { structure planked } \\
\text { with sheets of } \\
\text { diverse materials } \\
\text { (incl. composites) }\end{array}$ & $\begin{array}{l}\text { systemoriented, } \\
\text { function-integrated } \\
\text { Multi-Material-Mix }\end{array}$ \\
\hline $\begin{array}{l}\text { Additive } \\
\text { Manufacturing }\end{array}$ & Rapid tooling & \multicolumn{2}{|c|}{$\begin{array}{l}\text { increase of build-up-rate in SLM and } \\
\text { 3D-printers, new material models, } \\
\text { quality assurance and reproducability }\end{array}$} & $\begin{array}{l}\text { one-shot } \\
\text { production of } \\
\text { whole modules }\end{array}$ & $\begin{array}{l}\text { new design } \\
\text { paradigma } \\
\text { "Manufacturing for } \\
\text { Functionality“ }\end{array}$ \\
\hline $\begin{array}{l}\text { Flexible } \\
\text { Manufacturing } \\
\text { of Body-in- } \\
\text { white }\end{array}$ & $\begin{array}{l}\text { collaborating } \\
\text { robots }\end{array}$ & $\begin{array}{l}\text { body-in-white } \\
\text { after order- } \\
\text { penetration-point }\end{array}$ & $\begin{array}{l}\text { flexible joining } \\
\text { technologies (e.g. } \\
\text { remote laser) }\end{array}$ & $\begin{array}{l}\text { environment- } \\
\text { sensible handling } \\
\text { devices }\end{array}$ & $\begin{array}{l}\text { one piece flow for } \\
\text { all types of a } \\
\text { plattform }\end{array}$ \\
\hline $\begin{array}{l}\text { Autonomous } \\
\text { Final Assembly }\end{array}$ & $\begin{array}{l}\text { strict sequences } \\
\text { in flow }\end{array}$ & $\begin{array}{l}\text { human-machine } \\
\text { collaboration }\end{array}$ & flexibility in routes & $\begin{array}{l}\text { continuous re- } \\
\text { scheduling of } \\
\text { work-load }\end{array}$ & $\begin{array}{l}\text { labor- and } \\
\text { technology-flexibility }\end{array}$ \\
\hline $\begin{array}{l}\text { Re- } \\
\text { Manufacturing }\end{array}$ & $\begin{array}{l}\text { recover end-of-life } \\
\text { products to "as- } \\
\text { good-as new" } \\
\text { condition }\end{array}$ & $\begin{array}{l}\text { advancement in } \\
\text { inspection and } \\
\text { non-destructive } \\
\text { disassembly }\end{array}$ & $\begin{array}{l}\text { re-man activities } \\
\text { adaptive to } \\
\text { machine state }\end{array}$ & $\begin{array}{l}\text { universal re-man } \\
\text { standard for } \\
\text { multiple product } \\
\text { models }\end{array}$ & $\begin{array}{l}\text { cradle-to-cradle } \\
\text { product design for } \\
\text { remanufacturing }\end{array}$ \\
\hline
\end{tabular}

Figure 7. Summary of current trends and possible roads to achieve future goals.

and performance in the presence of system anomalies and severe disturbances, especially when the system operates under varying conditions, and (c) the inability of self-adjusting system configurations to mitigate internal faults and/or external intrusions to achieve survivability.

To meet these challenges, automotive factories need to go beyond "predictive maintenance" to intelligent "prognostics" - the process of pinpointing exactly which components of a machine are likely to fail and when to trigger service and to order spare parts autonomously. When smart products and machines are networked and remotely monitored and when their data is modeled and continually analyzed with sophisticated systems, it is possible to reach intelligent "prognostics". Figure 8 shows the unmet needs of future intelligent maintenance systems (IMS). IMS focuses on developing advanced degradation modeling and prediction as well as informatics tools for decision support systems.

The economic benefit of intelligent manufacturing and maintenance systems has to be measured in order to enable an optimization of internal and external services [63]. In order to help the automotive industry build smart factories with nearzero downtime performance, research is needed to create a systematic body of knowledge in intelligent maintenance systems and ultimately to impact next-generation product and service

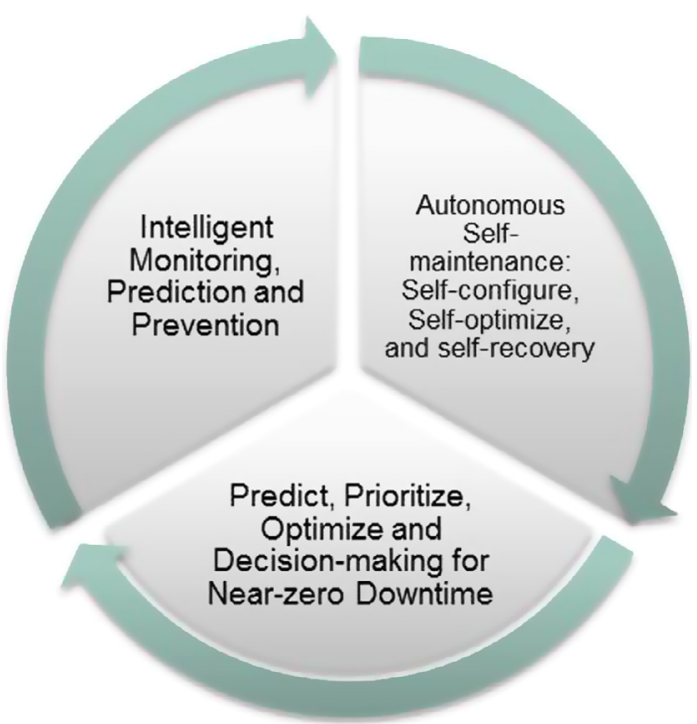

Figure 8. Needs and future trends for intelligent manufacturing and maintenance systems.

systems with near-zero breakdown performance [64]. The potential research areas for near-zero downtime production systems are listed as follows. 


\subsubsection{Machine immune systems}

Machine Immune System is a new design and system methodology that unleashes enormous potential for high performance and cost-effective automotive production systems. An engineering immune machine/system can monitor and diagnose itself, and if any kinds of failure or degradation happen, it can still maintain its functions for a while. In order to fulfill the machine immune function, intelligence is added to the machine, making it clever enough for functional maintenance.

\subsubsection{Decision support tools - predictive maintenance planning and service optimization application}

Design, control and management of maintenance activities in large production systems boost their productivities and increase their reliability and responsiveness to changing operations [65]. The intelligent decision support tools - as part of the solutions for tomorrow's vehicle production strategy - have the following several important issues that need to be addressed: They include (1) assessment of the impact of a machine breakdown on the factory throughput, (2) prioritization of maintenance tasks, (3) analysis of critical machine downtime effects, (4) identification of preventive maintenance opportunities, and (5) resource allocation (e.g. maintenance crews) on the critical sections of the systems [66]. Moreover, advanced decision support systems for the automotive industry should be based on integrated maintenance, production logistics and quality models to find the right balance between conflicting production objectives [67]. Future smart factories should leverage the maintenance intelligence to predict, prioritize, and plan the actions to achieve the "every action correct" objective.

\subsubsection{Embedded and networked prognostics systems - reconfigurable customizable platform}

To enable a production system with a self-maintenance and self-prognostics function, there are customized prognostics including embedded sensor systems with energy harvest capabilities, virtual models for augmented component life estimation (e.g. virtual bearings), and system reliability management. Collaborative efforts are required to explore new strategic areas, including self-maintenance systems, resilient systems and engineering immune systems. These new frontier efforts will lead to new transformational technologies in making future engineering systems with predictive and preventive capabilities that avoid potential issues.

\subsection{Advanced lean production}

Lean Production has been playing a role of overwhelming importance in production science for decades now - starting with Toyota back in the 1940 s and its worldwide spread in the last 20 years. Lean addresses two sides today - on the one hand it is a philosophy focusing on participation and motivation of employees but providing well-defined methods and approaches on the other hand. Some of the most crucial methods are just-in-time or just-in-sequence delivery, poka-yoke, continuous improvement processes, team work or andon boards. Especially in series production (starting from the automotive industry) lean has been established quite well. However, its adaptation to smaller production facilities with a very high variance of products is still a crucial point in research [68]. The current national initiative in Germany called "Industrie 4.0" $[69,70]$ or the Digital Manufacturing \& Design Innovation (DMDII) Institute in the US [71] are working on the integration of advanced solutions of modern information and communication technology (ICT) in production processes, equipment, factories, and supply chains. For the methodological side of lean, advances in ICT can help to reach new potentials e.g. by using partially automated value stream maps by consequent tracking of workpieces and carriers. Decentralized decision making and dynamic adjustments of kanbans might help to increase flexibility and resilience of lean production systems.

\subsection{Global production networks}

Value creation has become a globally distributed task. Using the best available production factors (e.g. to reduce labor and energy costs) as well as being close to the market (and in doing so, avoiding local-content penalties) are the most important reasons for going abroad. During the economic crisis in the US and the EU, the Chinese market acts as an anchor of stabilization. On the other hand, a crisis in one country can lead to turbulences in the supply chains, affecting all partners around the world. Consequently, the design and management of agile networks which share information and risk become of crucial importance [72].

The task for future research is the development of a holistic theory of global production, which enables science and industry to better understand and control global distributed production. There has to be a fusion of (existing) approaches to plan and control global production networks and production and operations management. Quality issues, problems in logistics, suppliers' performance or internal and external barriers (e.g. local-content or emission regulations) can erode expected benefits of a global production strategy. So far, science is not able to understand all interlinkages and influencing factors, which makes a sustainable optimization difficult. It can be stated that the importance of global production networks has increased in a way and speed that scientific methods and theories fail to follow so far. The challenges on the way to a comprehensive understanding of global production can be arranged in four levels: production network, production system, production process (manufacturing technology) and the product itself. Based on a simultaneous engineering approach between product development and production process description, the overall structure of a production line or whole factory at a certain location is determined and its performance analyzed, which affects site selection and requires the assessment of the interaction with the surrounding network. When it comes to the above discussed enabling core technologies (such as battery production for electric mobility and lightweight construction), this cycle is even more important. For high-wage countries in Europe it will be of crucial importance to perform better than others in enabling new technologies, and in doing so the competition between 


\begin{tabular}{|c|c|c|c|c|c|}
\hline Topic & 2014 & 2017 & 2020 & 2025 & Goal \\
\hline $\begin{array}{l}\text { Near-Zero } \\
\text { Downtime } \\
\text { Production } \\
\text { Performance }\end{array}$ & $\begin{array}{l}\text { intelligent } \\
\text { predictive } \\
\text { maintenance, } \\
\text { discovery of } \\
\text { hidden } \\
\text { opportunities }\end{array}$ & $\begin{array}{l}\text { smart factory with } \\
\text { near-zero } \\
\text { unscheduled } \\
\text { downtime } \\
\text { performance }\end{array}$ & \multicolumn{2}{|c|}{$\begin{array}{l}\text { integrated production, quality and } \\
\text { maintenance control in real-time }\end{array}$} & $\begin{array}{l}\text { production systems } \\
\text { with engineered } \\
\text { immune capability }\end{array}$ \\
\hline $\begin{array}{l}\text { Advanced } \\
\text { Lean } \\
\text { Production }\end{array}$ & $\begin{array}{l}\text { lean principles } \\
\text { established in } \\
\text { series production }\end{array}$ & \multicolumn{2}{|c|}{$\begin{array}{l}\text { methods of lean produciton adapted to } \\
\text { small series production with high } \\
\text { variance in volatile environments }\end{array}$} & $\begin{array}{l}\text { new potential } \\
\text { enabled by real- } \\
\text { time data } \\
\text { collection }\end{array}$ & $\begin{array}{l}\text { optimal balance } \\
\text { between leanness } \\
\text { and resilience }\end{array}$ \\
\hline $\begin{array}{l}\text { Global } \\
\text { Production } \\
\text { Networks }\end{array}$ & $\begin{array}{l}\text { hierarchical } \\
\text { chains }\end{array}$ & $\begin{array}{l}\text { localisation of } \\
R \& D\end{array}$ & \multicolumn{2}{|c|}{$\begin{array}{l}\text { transformation of chains to networks } \\
\text { with lead plants (vertical and } \\
\text { horizontal integration) }\end{array}$} & $\begin{array}{l}\text { agile networks with } \\
\text { risk- and } \\
\text { information sharing }\end{array}$ \\
\hline
\end{tabular}

Figure 9. Summary of current trends in outer effects of production.

companies will be a competition between their production networks. For the headquarters, usually in high wage countries, this means to use the internal competition to push innovations in product and production technology simultaneously and steadily - for instance by creating a role-model (so called lead plants) for the production of the latest product technologies with the latest manufacturing technologies, which is rolled out in all other countries again and again.

The automotive industry has changed from a "one-factoryfor-the-world" to a "hub-and-spoke-approach" and holds on for the next step in becoming a real partnership-based network. Even huge OEMs open their doors of R\&D for suppliers and universities. Networks do not offer economies-of-scales like the "world-factory" or a hub, but they enable the highest level of flexibility as capacities can be arranged. However, for networks to perform well, the ability to overcome "egoisms" of single plants and single countries is required. As one part of the individualization trend, an adaptation of products to regional and cultural tastes is getting more and more important. Therefore, $R \& D$ has started to follow production plants which have been following the markets for decades now. The localization of R\&D can be seen as the next step of globalization, which has already started.

\subsection{Summary of production management}

Figure 9 summarizes the mentioned aspects of production management.

\section{Conclusion}

The goal of the automotive industry in developed countries like Japan, Korea, USA, and Germany is to increase sustainability in terms of being profitable, ecological, and socially compatible. New product and production technologies have to be integrated, new cooperations managed and customer satisfaction increased by localization and individualization, while production costs stay competitive due to smart and flexible factories.
This paper presents a review on recent developments in industry and science with a focus on manufacturing technologies as well as organizational issues in automotive industry. Moreover, it presents potential trends. However, it must be stated that the paper of course is limited to subjective extrapolation done by the authors. Moreover, key technologies such as aerodynamics or (partially) autonomous driving and innovative sensors are not observed - also they might have impacts on production as well.

\section{References}

1. ACEA - European Automobile Manufacturers' Association (2012) http://www.acea.be/images/uploads/files/ACEA_ POCKET_GUIDE_2012_UPDATED.pdf, accessed in August 2013.

2. SelectUSA (2013) http://selectusa.commerce.gov/industrysnapshots/automotive-industry-united-states, accessed in July 2013.

3. Jama - Japan Automobile Manufacturers Association (2012) http://autobeatinsider.com/wp-content/uploads/2012/06/JAMA2012-report.pdf, accessed in July 2013.

4. KPMG (2013) http://www.kpmg.com/KZ/ru/IssuesAndInsights/ ArticlesAndPublications/Documents/KPMGs-Global-AutomotiveExecutive-Survey-2013.pdf, accessed in July 2013.

5. APCO (2010) http://www.export.gov.il/uploadfiles/03_2012/ chinasautomotiveindustry.pdf, accessed in July 2013.

6. W. Rohroff (2011) http://rohroff.de/Chinas_12_5JP_20112015.pdf, accessed in November 2013.

7. B. Nunes, Journal of Manufacturing Technology Management 19 (2008) 8.

8. J. Kurfer, M. Westermeier, C. Tammer, G. Reinhart, CIRP Annals - Manufacturing Technology 61 (2012) 1.

9. K.-J. Lee, G.-H. Kim, K. Smith (2010) http://www.nrel. gov/vehiclesandfuels/energystorage/publications.html\#p2010, accessed in August 2013.

10. A. Thielmann, R. Isenmann, M. Wietschel (2010) http:// www.isi.fraunhofer.de/isi-media/docs/t/de/publikationen/TRMLIB2030.pdf, accessed in September 2013. 
11. A. Menn (2014) http://www.handelsblatt.com/technologie/ forschung-medizin/forschung-innovation/airbus-plaene-dersaubere-elektro-flug/9807318.html?utm_medium=twitter\&utm source $=$ twitterfeed.

12. K. Amine, J. Lu, A. Abouimrane, H. Wu, Z. Zhang, P. Du, I. Belharouak, J. Yang, Y.K. Sun, L. Curtiss, Argonne National Laboratory, 2012, http://bestar.lbl.gov/bli5/files/2012/06/Amine session3.pdf.

13. P. Yi, L. Peng, L. Feng, P. Gan, X. Lai, Journal of Power Sources 195 (2010) 20, http://www.sciencedirect.com/science/ article/pii/S037877531000844X.

14. US Department of Energy (DOE) (2009) http://www.hydrogen. energy.gov/pdfs/epact_report_sec811.pdf, accessed in July 2013.

15. US Department of Energy (DOE) (2011) http://www1.eere. energy.gov/hydrogenandfuelcells/mypp/pdfs/fuel_cells.pdf, accessed in August 2013.

16. Y. Wang, K.S. Chen, J. Mishler, S.C. Cho, X.C. Adroher, Applied Energy 88 (2011) 4.

17. S. Karimi, N. Fraser, B. Roberts, F.R. Foulkes, Advances in Materials Science and Engineering 2012 (2012).

18. L. Peng, X. Lai, P. Yi, J. Mai, J. Ni, Transactions of the ASME: Journal of Fuel Cell Science and Technology 8 (2011) 1.

19. Y. Yu, H. Li, H. Wang, X.-Z. Yuan, G. Wang, M. Pan, Journal of Power Sources 205 (2012).

20. Z.-B. Wang, P.-J. Zuo, Y.-Y. Chu, Y.-Y. Shao, G.-P. Yin, International Journal of Hydrogen Energy 34 (2009) 10.

21. R.A. Antunes, M.C.L. Oliveira, G. Ett, V. Ett, International Journal of Hydrogen Energy 35 (2010) 8.

22. P. Yi, L. Peng, T. Zhou, H. Wu, X. Lai, International Journal of Hydrogen Energy 38 (2013) 3.

23. Fuel Cell Today, D. Carter, M. Ryan, J. Wing (2012) http://www.fuelcelltoday.com/analysis/industry-review/2012/theindustry-review-2012, accessed in July 2013.

24. Fuel Cell Partnership (2012) http://www.cafcp.org/roadmap, California, accessed in August 2013.

25. National Energy Administration of China (2012) http:// www.nea.gov.cn/2012-09/27/c_131875692.htm, accessed in July 2014.

26. Fuel Cell Europe (2010) http://ec.europa.eu/clima/consultations/ 0005/registered/88980385100-51_fuelcelleurope_en.pdf, accessed in August 2013.

27. WorldAutoSteel (2011) http://c315221.r21.cf1.rackcdn.com/ FSV_OverviewReport_Phase2_FINAL_20110430.pdf, accessed in November 2013.

28. Advanced Manufacturing Portal, http://www.manufacturing.gov/ $\operatorname{lm} 3$ i.html, accessed in July 2014.

29. USDrive (2013) https://www1.eere.energy.gov/vehiclesandfuels/ pdfs/program/mtt_roadmap_august2013.pdf, accessed in December 2013.

30. NanoSteel, http://nanosteelco.com/redefining-steel/alloy-designstrategy/, accessed in July 2014.

31. M. Chlipala, S. Stockey, M. Hirtler, V. Schulze, G. Lanza, Proceedings of the 14th international conference of the european society for precision engineering and nanotechnology (2014) pp. 170-173.

32. J. Fleischer, A. Ochs, S. Dosch, in New Developments in Sheet Metal Forming: Papers of the International Conference on Developments in Sheet Metal Forming M. Liewald (Ed.), MAT INFO Werkstoff-Informationsgesellschaft, Stuttgart, 2012.
33. G. Davies, Materials for Automobile Bodies, Elsevier, Oxford, 2012.

34. McKinsey \& Company (2012) http://www.mckinsey.com/ $\sim /$ media/mckinsey/dotcom/client_service/Automotive $\% 20$ and $\% 20$ Assembly/PDFs/Lightweight_heavy_impact.ashx, accessed in April 2014.

35. Fraunhofer Institute for Chemical Technology (2013) http:// www.ict.fraunhofer.de/en/comp/pe/hfv/thermoset_RTM_process. $\mathrm{html}$, accessed in August 2013.

36. J. Fleischer, A. Ochs, S.-F. Koch, in Technologies and Systems for Assembly Quality, Productivity and Customization, Proceedings of the 4th CIRP Conference on Assembly Technologies and Systems, Ann Arbor, Michigan, 2012, S.J. Hu (Ed.), CIRP, Ann Arbor Michigan, 2012, p. 7.

37. W. Hufenbach (2013) http://www.tudresden.de/die_tu_dresden/ fakultaeten/fakultaet_maschinenwesen/ilk/forschung/ineco_ projekt, accessed in November 2013.

38. Automotive Council Technology Group (2013) http://www. automotivecouncil.co.uk/wp-content/uploads/2013/09/Lightweight1. jpg, accessed in December 2013.

39. L. Mortara, J. Hughes, P.S. Ramsundar, F. Livesey, D. Probert, Rapid Prototyping Journal (2009).

40. European Technology Platform Photonics21 (2013) http:// www.photonics21.org/download/PhotonicsMultiannualRoadmap/ PhotonicsMultiannualStrategicRoadmapDocument.pdf, accessed in December 2013.

41. T. Rockstroh, D. Abbott, K. Hix, J. Mook, Industrial Lasers (2013) http://www.industrial-lasers.com/articles/print/volume28/issue-6/features/additive-manufacturing-at-ge-aviation.html, accessed in July 2014.

42. C. Emmelmann, D. Herzog, J. Kranz, C. Klahn, M. Munsch, Industrie Management (2013) 2.

43. L.E. Murr, S.M. Gaytan, D.A. Ramirez, E. Martinez, J. Hernandez, K.N. Amato, P.W. Shindo, F.R. Medina, R.B. Wicker, Journal of Materials Science \& Technology 28 (2012) 1.

44. Roland Berger Strategy Consultants (2013) http://www. rolandberger.com/media/pdf/Roland_Berger_Additive_Manufacturing 20131129.pdf, accessed in April 2014.

45. Advanced Manufacturing Portal, http://www.manufacturing. gov/nnmi_pilot_institute.html, accessed in July 2014.

46. Direct Manufacturing Research Center, http://dmrc.uni-paderborn.de/ fileadmin/dmrc/Download/data/DMRC_Studien/DMRC_Study.pdf, accessed in July 2014.

47. Diginova (EU Project, FP7) (2014) http://www.diginovaeu.org/ content/dam/diginova/en/documents/Digital_Fabrication_eBook. pdf, accessed in July 2014.

48. Volkswagen, Industrial Robot: An International Journal (2006) 30.

49. S. Makris, G. Michalos, G. Chryssolouris, Robotics and Computer-Integrated Manufacturing 28 (2012) 3.

50. J. Fleischer, J. Schaedel, CIRP Journal of Manufacturing Science and Technology 6 (2013) 2.

51. J.-E. Gans, G. Lanza, R. Müller, S. Peters, L. Schoen, wt Werkstattstechnik online (2011) 3.

52. T. Bauernhansl, interaktiv - Fraunhofer IPA (2012) 2.

53. S. Nördinger, Produktion (2013) http://www.produktion.de/forschungentwicklung/arena2036-flexibilisiert-die-automobilproduktion/ accessed in July 2014.

54. X. Jin, S.J. Hu, J. Ni, G. Xiao, IEEE Transactions on Automation Science and Engineering 10 (2013) 1. 
55. X. Jin, J. Ni, Y. Koren, CIRP Annals - Manufacturing Technology 60 (2011) 1.

56. R.T. Lund, Technology Review 87 (1984) 2.

57. M.E. Ferguson, in Closed-loop supply chains: new developments to improve the sustainability of business practices, M.E. Ferguson, G.C. Souza (Eds.), CRC Press, Boca Raton, Florida 2010.

58. A. Brusaferri, M. Colledani, G. Copani, N. Pedrocchi, M. Sacco, T. Tolio, The 10th Global Conference on Sustainable Manufacturing - Towards Implementing Sustainable Manufacturing, Istanbul, 2012, p. 332.

59. V.D.R. Guide, J. Li, Decision Sciences 41 (2010) 3.

60. J. Gerrard, M. Kandlikar, Journal of Cleaner Production 15 (2007) 1

61. D. Froelich, E. Maris, N. Haoues, L. Chemineau, H. Renard, F. Abraham, R. Lassartesses, Minerals Engineering 20 (2007) 9.

62. N. Perry, A. Bernard, F. Laroche, S. Pompidou, CIRP Annals Manufacturing Technology 61 (2012) 1.

63. G. Lanza, D. Appel, in Symposium Proceedings International Applied Reliability Symposium - Europe 2012, ReliaSoft Corporation (Ed.), p. 1.

64. J. Ni, X. Jin, CIRP Annals - Manufacturing Technology 61 (2012) 1 .

65. Y. Koren, The Global Manufacturing Revolution: ProductProcess-Business Integration and Reconfigurable Systems, John Wiley \& Sons, Hoboken, New Jersey, 2010.
66. M. Colledani, M. Ekvall, T. Lundholm, P. Moriggi, A. Polato, T. Tolio, International Journal of Production Research 48 (2010) 7 .

67. M. Colledani, T. Tolio, CIRP Annals - Manufacturing Technology (2012) 61, 1.

68. J. Fleischer, G. Lanza, K. Peter, Quantified Interdependencies between Lean Methods and Production Figures in the Small Series Production, in Conference Proceedings MS 2008, 41st CIRP Conference on Manufacturing Systems, 26.05.200828.05.2008, Tokyo, Japan, pp. 89-92.

69. Acatech, http://www.acatech.de/fileadmin/user_upload/ Baumstruktur_nach_Website/Acatech/root/de/Material_fuer_ Sonderseiten/Industrie_4.0/Final_report_Industrie_4.0_accessible. pdf, accessed in July 2014.

70. Deutsche Bank Research, http://www.dbresearch.de/PROD/ DBR_INTERNET_EN-PROD/PROD0000000000333571/Industry + 4_0\%3A+Upgrading + of + Germany $\% \mathrm{E} 2 \% 80 \% 99 \mathrm{~s}+$ industrial + capabilities+on+the+horizon.pdf, accessed in July 2014.

71. Advanced Manufacturing Portal, http://www.manufacturing. gov/dmdii.html, accessed in July 2014.

72. G. Lanza, N. Stricker, S. Peters, Procedia CIRP (2013) 7.

Cite this article as: Peters S, Lanza G, Ni J, Xiaoning J, Pei-Yun Y \& Colledani M: Automotive manufacturing technologies - an international viewpoint. Manufacturing Rev. 2014, 1, 10. 